\title{
WORKERS' HOUSING ESTATES IN POSTINDUSTRIAL CITIES - MODERNIZATION OR REVITALIZATION?
}

\author{
Dariusz GAWEŁ ${ }^{1}$ \\ Kielce University of Technology, Faculty of Civil Engineering and Architecture, \\ Kielce, Poland
}

\begin{abstract}
The article presents a part of the results on the physiognomy of a postindustrial city under conditions of economic transformation in Poland. The study area encompasses industrial centers located in the region of the Central Industrial District (Centralny Okręg Przemysłowy - COP) in the Świętokrzystkie and Mazowieckie voivodeships (districts). The specific urban structure of the industrial city and unemployment among its inhabitants resulting from ownership transformations generate various problems. The workers' neighborhoods and colonies, which sprouted up so quickly at the beginning of the XX century, were a supply base for the rapidly developing industrial centers. Their clear urban structure and cultural potential they possess predispose them to developing necessary repair programs. Thus, the article draws attention to this form of settlement on the one hand, and on the other characterizes the activities assumed by gminas (municipalities) in the scope of modernizing and revitalizing these areas.
\end{abstract}

Keywords: workers' housing estates, postindustrial city, modernization, revitalization

\section{ASSUMPTIONS BEHIND WORKERS' NEIGHBORHOODS AND COLONIES}

Rapidly appearing workers' colonies and neighborhoods became the basic form of industrial settlement at the beginning of the XX century. Their specifics (rural and urban neighborhoods) and nature of the housing development

\footnotetext{
${ }^{1}$ Corresponding author: Kielce University of Technology, Faculty of Civil Engineering and Architecture, al. Tysiąclecia Państwa Polskiego 7, 25-314 Kielce, Poland, e-mail: dg@vp.pl
} 
determined the urban fabric for many years, remaining the basic form of development in the outskirts of industrial cities.

A specific characteristic of these types of neighborhoods is that the buildings were constructed in wide-spanning areas which belonged to the gmina (municipality) or state; the development was treated as peripheral, or based along the stretch of a street [5].

The composition of the social structure of these neighborhoods most often decided about the choice of urban form. Migrations of the urban population to cities (caused by agrarian overpopulation of 84 people per hectare) gave perspectives of getting rich quickly [7]. Rural neighborhoods with accompanying plots of farmland made it possible to combine working in an industrial plant with farming. These neighborhoods, first built by factory owners as small agglomerations of houses (thus the original term: patron settlements), began to rapidly develop over time as the result of a state aid program.

The catastrophic condition of Polish housing was clearly expressed in the general census conducted in 1921, which revealed a shortage of 1.5 million rooms. Single-room dwellings comprised as many as $60 \%$ of all apartments, e.g. in Łódź [2].

The scale of urban development was strictly connected with the scale of the industrial center. In smaller cities, modest concentrations of buildings appeared - so called colonies. The buildings usually took the form of small residential houses for 4 to 8 families. In larger cities, multi-family housing, usually 4 stories high, prevailed. The style most often applied to residential buildings referred to various forms of historicism.

Along with the newly created residential development, public facilities in the form of schools, cultural centers (referred to as casinos at the time) or shops were formed. The conditions of the created living environment enabled the economic development of these cities.

Workers' colonies (as settlements and housing development complexes) in cities of the Central Industrial District did not create such unique spatial-architectural forms as in Silesia or in areas around Łódź, however they stood out in terms of their scale. Built as spatial compositions in the form of modest residential interiors of multi-family housing estates, linear villages or linear development along a street with front gardens, they created clear urban planning schemes which have survived to this day.

Nowadays, workers' estates are becoming synonymous to poverty and social pathology. The lack of renovation work and too hasty changes in ownership rights remain the main reason behind the spatial degradation of entire neighborhoods. 


\section{ANALYSIS OF EXAMPLES OF WORKERS' DEVELOPMENTS}

A Polish industrial city on the verge of the XIX and XX centuries was usually characterized by a loose spatial structure filled in with dominants, i.e. industrial buildings and social facilities (churches, schools, administrative offices). While historic urban layouts were characterized by the simplicity of solutions, modern-day industrial cities are a very complex system combining numerous and specialized types of places [1]. Industrial buildings, due to their functional characteristics and individual system of technological, logistic and transportation connections influenced the form that development within cities took. Larger manufacturing plants, in addition to warehouses and technical buildings, often became surrounded by residential neighborhoods. That is why we can refer to designated industrial zones of a city, and sometimes entire districts [4] created from industrial and warehouse buildings and residential developments.

Table 1. Architectural-spatial features of analyzed workers' neighborhoods and colonies

\begin{tabular}{|c|c|c|c|c|c|c|}
\hline No. & City & $\begin{array}{c}\text { Nature of } \\
\text { development }\end{array}$ & $\begin{array}{c}\text { Number } \\
\text { of flats }\end{array}$ & $\begin{array}{c}\text { Number } \\
\text { of stories }\end{array}$ & Land usage & $\begin{array}{c}\text { Direct } \\
\text { neighborhood }\end{array}$ \\
\hline 1 & 1 & 2 & 3 & 4 & 5 & 6 \\
\hline 2 & $\begin{array}{c}\text { Ostrowiec } \\
\text { Świętokrz } \\
\text { yski }\end{array}$ & $\begin{array}{c}\text { Single- } \\
\text { family } \\
\text { housing }\end{array}$ & 116 & 1 & agriculture & $\begin{array}{c}\text { Single-family } \\
\text { development } \\
\text { cemetery }\end{array}$ \\
\hline 3 & $\begin{array}{l}\text { Skarżysko } \\
\text { Kamienna }\end{array}$ & $\begin{array}{c}\text { Small houses } \\
(8-f a m i l y)\end{array}$ & 272 & 2 & $\begin{array}{c}\text { outbuildin } \\
\text { gs }\end{array}$ & $\begin{array}{c}\text { Single-family } \\
\text { development } \\
\text { cemetery }\end{array}$ \\
\hline Radom & $\begin{array}{l}\text { Multi-family } \\
\text { Terraced } \\
\text { housing }\end{array}$ & 337 & $4 / 5$ & $\begin{array}{c}\text { greenery, } \\
\text { playground } \\
\text { s }\end{array}$ & $\begin{array}{c}\text { Multi-family } \\
\text { development } \\
\text { City greenery }\end{array}$ \\
\hline
\end{tabular}

\subsection{Ostrowiec Świętokrzyski - Workers' colony}

Traditional iron smelting in the Swiętokrzyskie region dates back to the beginnings of our era (II - IV CE). It is here that the oldest Polish furnaces used for smelting iron from mining ores (limonite and hematite) were discovered. The Staszic conception of the development of centers located on the Kamienna River based on the mining industry (of iron ore and coal) also anticipated processing these raw materials. One such location was the steel mill in Ostrowiec Swiętokrzyski. The produced steel elements were used not only for meeting the needs of regional factories, but also distributed to other regions of Poland; thus, the very well developed network of rail connections in the region. The steel mill in Ostrowiec was a vividly developing plant, attracting the populations of neighboring towns and villages, hence the nature of this 
settlement form as a rural colony, based on development in the form of small single-family homes with appurtenant plots of farmland [9]. The colony was located outside of the borders of the city, northeast of its center. Basing the urban planning scheme on linear development (today somewhat blurred by the progressing urbanization of the suburban area of the city), made for the spatial clarity of the composition. Forming the settlement structure with a receding building alignment made it possible to organize small front gardens. The borders of small parcels of farmland were naturally established by the proximity of forests, and later the placement of a cemetery and allotment gardens. Architectural development in the form of single family residential buildings had a significant influence on the level of the population flooding in from rural areas and improvement of their living standards.



Fig. 1. 2. Development of characteristic small single-family houses forming the Workers' Colony in Ostrowiec Świętokrzyski (photograph taken by the author 2014)

\subsection{Skarżysko Kamienna - Workers' Colony on Staffa street}

Skarżysko, as a significant center for heavy industry and arms manufacturing was also an important junction for rail transportation on the railway line from Warsaw to Cracow and Upper Silesia. It was these branches of industry that, for many years, stimulated the intensive growth of the industrial city. The Workers' Colony located on the outskirts of the city in the Zachodnie (West) district of Skarżysko Kamienna was created as one of two neighborhoods (Workers' Colony and Kolonia Górna - Upper Colony) formed in 1925, and intended for the primary work force of the National Ammunition Factory. Designed as an urban planning scheme in the form of small free-standing 8-family, 2-storey houses, it called for placing 34 buildings along Staffa Street and the adjoining streets (the main compositional axis of the neighborhood). The fenced-off properties also had outbuildings on their lots. In addition to housing 
development, social infrastructure in the form of an elementary school was also developed.

What distinguishes the development is the simple architectural form of the buildings enhanced by details. The brick and broken stone construction completed with light brick corner elements, cornices and window frames set the buildings apart in terms of esthetics. The color scheme made it possible to combine toned down hues of yellow with light silicate brick.

\subsection{Radom - Planty Neighborhood}

In the direct proximity of the Arms Factory in Radom, a large 23 hectare estate was built on the lot where Mariackie Farm used to be. The neighborhood was designed by the famous architect - Stefan Szyller (a representative of Polish historicism), and included 337 dwellings in multi-family housing intended for workers and senior management [10].

Locating the new residential development on the outskirts of the city had anticipated drawing from a popular concept at the time, i.e. the inclusion of buildings in green complexes (so-called "planty" or urban greenery). Thus, the idea of drawing attention to green areas was propagated, and particularly popular in some cities (e.g. in the Cracow environment, proud of its urban greenery) [6].

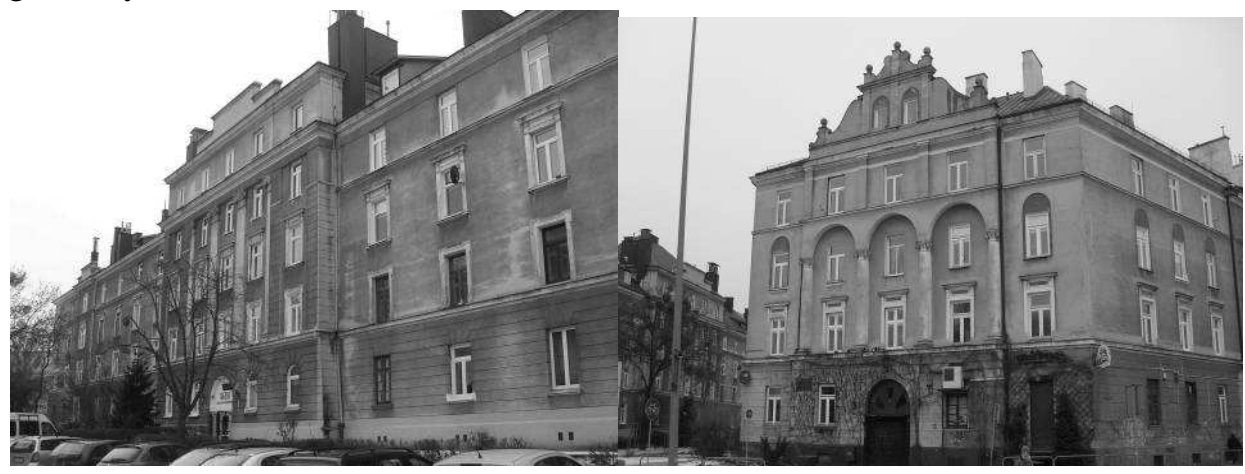

Fig. 3, 4. Buildings in the "Planty Neighborhood" of Radom are situated along the streets, creating spacious living interiors - currently partially built up (photograph taken by the author, 2014)

The neighborhood also stood out in terms of the attention given to public facilities in the form of spas, bakeries and a factory "casino" located in the neighborhood. Four- and five-storey buildings were situated along streets, creating spacious living interiors, and the area around them completed with playgrounds, sandboxes, fountains or a clock column. 
The designer proposed long terraced buildings in the new Polish renaissance style, which was fashionable at the time, with rustication, multi-level cornices, attics, and decorative window frames.

The spatial standard of the apartments varied greatly, from multi-room, 90 square meter apartments to single-room studios. However, all apartments were equipped with bathrooms and toilets.

\section{TECHNICAL CONDITIONS OF HOUSING DEVELOPMENT}

The technically exploited residential buildings did not present much economic value to their owners. Transferred over to municipalities along with land property and renters, they became a further problem in the municipal social housing stock.

In the absence of developed multi-stage (as a result of the scope of multifaceted activities) but also individual (due to the specifics of historical buildings) revitalization programs, the activities of new owners and property managers were limited to necessary repairs.

The modest spatial standard of the majority of dwellings as well as the fragmentation of ownership (a portion of these houses were transferred over to renters for a modest payment), often restricts the possibility of major renovation.

Outside walls failing to comply with the heat retention standards of partitions, worn windows and doors, and the lack of economical heating systems are the biggest problems that the inhabitants are occupying the buildings are faced with.

On the other hand, the material (stone) used or extensive architectural detail, make it impossible to quickly and effectively carry out comprehensive thermo modernization work on the buildings. The fact that the buildings are not connected to the city's central heating system, which would make it possible to change over from coal heating, has made it necessary for owners to seek alternative solutions, including the installation of gas furnaces (used for heating the dwelling as well as water). However, the limited amounts of smoke and fume ducts available have posed a serious problem. The buildings were usually equipped with basic building installations, however fulfilling current requirements, if merely in terms of room ventilation, can prove unfeasible.

The nature of actions taken by the municipality more and more often comes down to a form of modernization that is limited to improving the technical state, while paying attention to the esthetics of the buildings, their surroundings, or the living conditions of their inhabitants. 


\section{POST-INDUSTRIAL CITY IN THE TRANSFORMATION PHASE}

The analysis of the issue of transformation and metamorphosis of an industrial city into a postindustrial one ought to be viewed in the categories of economic changes taking place in our country after 1990 . These changes significantly affected the development of urban space, especially in postindustrial cities.

On the other hand, the historic background, an effect of buildings connected with the arms and mining industries being located in this region, influenced how the urban structure of industrial centers has been shaped, with elements of regional architectural features [3]. The modest city centers, besides a small historical center, do not possess a compact urban structure. While socioeconomic phenomena continue to be a reflection of post-industrial city transformations, these also include spatial phenomena, such as:

- closing down unprofitable industrial plants,

- changes in the ratio of rent to ownership

- an increase in unemployment and impoverishment of society

- the depopulation of these cities and their gentrification

- social and spatial degradation of entire neighborhoods.

Nowadays, postindustrial cities containing abandoned industrial buildings in their structure are losing not only a source of economic sustainment but also their spatial clarity.

Revitalization programs are providing them with a great chance, due to the possibility of obtaining funding from the outside. As results from the carried out studies, revitalization activities, however, are usually limited to public spaces within city centers. The housing issue in revitalization programs is usually treated marginally, both from the point of view of investment activities and financing from public resources; modernization activities are carried out on a point-to-point basis and affect only individual buildings [8].

\section{CONCLUSIONS}

Workers' colonies are historically developed forms of settlement which are a manifestation of the historical heritage of industrial cities. Developed based on the novel concepts of a "garden city", they became an expression of modern urban thought, allowing for the diffusion of the cities' problems. Created based on new architectural design standards, they influenced the improvement of sanitary, technical and social conditions of rural population masses flooding into the cities. 
Today, what remains of the workers' colonies is becoming a reflection of various problems connected with the functioning of postindustrial cities. The fragmentation of ownership rights to small dwellings requires the increased social participation of inhabitants of these neighborhoods in order to improve their technical condition.

Targeted support of the residents of these neighborhoods is becoming a responsibility of local self-governments to prevent the spatial degradation of cites. Seeking adequate forms of modernizing these areas ought to extend beyond the scope of revitalization and strategic city development programs. The social degradation of inhabitants also ought to be counteracted by the proper organization and shaping of the living environment.

\section{REFERENCES}

1. Chmielewski J.M.: Teoria urbanistyki w projektowaniu i planowaniu miast, Oficyna Wydawnicza Politechniki Warszawskiej, Warszawa 2001.

2. Chmielewski J.M. Mirecka M.: Modernizacja osiedli mieszkaniowych, Oficyna Wydawnicza Politechniki Warszawskiej, Warszawa 2007

3. Furtak M.: Genius loci architektury COP (na przyktadzie rejonu A) rękopis pracy doktorskiej, Repozytorium Politechniki Krakowskiej, Kraków 2007

4. Gaweł D.: Rebirth of postindustrial architecture in polish towns,w. Civil and Environmental Engineering Reports, University of Zielona Góra, 9(2012) 31-39

5. Krasowski W.: Problemy architektury polskiej, Schematy planów budynków mieszkalnych,Oficyna Wydawnicza Politechniki Warszawskiej, Warszawa 2007

6. Rymaszewski B.: O przetrwanie dawnych miast, Arkady, Warszawa 1984

7. Samecki W.: Centralny Okręg Przemystowy 1936-39, Wstepna faza programu uprzemystowienia, Wydawnictwo Uniwersytetu Wrocławskiego 1989

8. Zaniewska H.: Architektoniczno-urbanistyczne $i$ spoteczne aspekty dostosowania powojennej zabudowy osiedlowej do standardów XXI wieku, w. Przeglad budowlany, Warszawa, 3(2012) 145-148

9. http://koloniarobotnicza.wix.com/historiamowiona - dostępność 07.01.15

10. http://m.radom.gazeta.pl/radom/56,106518,12869917 -dostępność 07.01.15 


\section{OSIEDLA ROBOTNICZE W MIASTACH POSTINDUSTRIALNYCH - MODERNIZACJA CZY REWITALIZACJA?}

\section{Streszczenie}

Artykuł jest przedstawieniem części badań nad fizjonomią miasta postindustrialnego w warunkach transformacji ekonomicznej w Polsce. Pole badawcze obejmuje ośrodki przemysłowe rozmieszczone na terenie Centralnego Okręgu Przemysłowego, w województach świętokrzyskim i mazowieckim (Ostrowiec Świętokrzyski, Skarżysko Kamienna, Radom). Specyficzna struktura zabudowy miasta industrialnego oraz bezrobocie wśród mieszkańców będące wynikiem przekształceń własnościowych generują różne problemy rozwojowe. Zabudowa mieszkaniowa obok przemysłowej stanowiła podstawę funkcjonowania struktury ośrodka przemysłowego. Powstające żywiołowo osiedla i kolonie robotnicze na początku XX w. były zapleczem dla szybko rozwijających się miast przemysłowych. Ich czytelny układ urbanistyczny i potencjał kulturowy jaki posiadają predysponują je do opracowania niezbędnych programów naprawczych. Stąd artykuł jest z jednej strony zwróceniem uwagi na tę formę osadnictwa, a z drugiej charakterystyką działań gminnych w zakresie modernizacji i rewitalizacji takich terenów. Jednak problematyka mieszkaniowa w programach rewitalizacyjnych często traktowana jest marginalnie, zarówno $\mathrm{z}$ punktu widzenia działań inwestycyjnych jak i finansowania ze środków publicznych, a działania modernizacyjne prowadzone są punktowo i dotyczą zazwyczaj tylko pojedynczych budynków.

Słowa kluczowe: osiedla robotnicze, miasto postindustrialne, modernizacja, rewitalizaja

Editor received the manuscript: 21.12.2014 
